\title{
Analisis UNCLOS 1982 Terkait Permasalahan Yurisdiksi Negara dan Penegakan Hukum Atas Kapal Berbendera Negara Asing
}

\section{Zainal Abdul Aziz Hadju}

Pascasarjana Ilmu Hukum Universitas Padjadjaran, Bandung, Indonesia E-mail: zainal18001@mail.unpad.ac.id

\begin{tabular}{|c|c|c|}
\hline \multicolumn{2}{|c|}{ Dikirim: 04/02/2020 } & Dipublikasi: $25 / 3 / 2021$ \\
\hline Info Artikel & & Abstract \\
\hline $\begin{array}{l}\text { Keywords: } \\
\text { UNCLOS } \\
\text { Yurisdictio; } \\
\text { Enforcement. }\end{array}$ & 1982; & $\begin{array}{l}\text { International Law has reign most interactions between States in the sea. The } \\
\text { practice of illegal transshipment is a serious issue as it falls within both } \\
\text { theft mode and smuggling through the transfer of cargo from one ship to } \\
\text { another that occurs at sea. Including a crime which committed in the } \\
\text { territory of one state but involving parties from another state or more. Law } \\
\text { enforcement is a major concern when an offence of some kind of illegal } \\
\text { transshipment occurs. The study aims to determine the jurisdiction of states } \\
\text { in enforcing laws including in criminal matters that occurred over its sea } \\
\text { where the country has sovereign rights, especially when the involvement of } \\
\text { 3rd states party in the law enforcement on a ship which not entered into its } \\
\text { territory, yet indicately committed a violation of the law in some states water } \\
\text { area, this paper also study how the responsibility of } 3^{\text {rd }} \text { states party towards } \\
\text { of flag states of ships who feel harmed. This article was written using } \\
\text { normative research methods with a statutory. Historical and conceptual } \\
\text { approach explaining efforts from international organizations in resolving } \\
\text { the issues of accountability of countries involved in the problem of Illegal } \\
\text { Transshipment at sea in the } 1982 \text { UNCLOS perspective especially the } \\
\text { process of law enforcement and dispute resolution by the International } \\
\text { Tribunal for the Law of The Sea (ITLOS). }\end{array}$ \\
\hline
\end{tabular}

Kata Kunci: UNCLOS 1982 Yurisdiksi; Penegakkan Hukum.

\section{Abstrak}

Hukum internasional telah mengatur segala interaksi Negara-negara di wilayah laut. Praktik illegal transshipment merupakan suatu permasalahan yang serius karena termasuk dalam modus pencurian maupun penyeludupan melalui pemindahan muatan dari satu kapal ke kapal lainnya yang terjadi di laut. Meliputi kejahatan yang dilakukan di wilayah satu negara namun melibatkan pihak-pihak dari negara lain (dapat lebih dari 1 negara). Penegakan hukum menjadi perhatian utama saat terjadi pelanggaran semacam illegal transshipment. Penelitian ini bertujuan untuk menentukan yurisdiksi negara-negara dalam menegakkan hukum termasuk permasalahan criminal yang terjadi di atas lautnya dimana negara tersebut memiliki hak berdaulat, salah satunya adalah mengenai terlibatnya negara pihak ke-3 terhadap penegakan hukum atas kapal yang tidak masuk kedalam wilayahnya akan tetapi terindikasi pernah melakukan pelanggaran hukum di wilayah laut negaranya, termasuk bagaimana bentuk tanggungjawab secara material dan immaterial terhadap negara bendera dari kapal yang merasa dirugikan. Artikel ini ditulis dengan menggunakan 
DOI:

10.47268/sasi.v27i1.254

metode penelitian normatif dengan pendekatan perundangan-undangan. Sejarah dan konseptual yang menjelaskan upaya dari organisasi internasional dalam menyelesaikan masalah pertanggungjawaban negaranegara yang terlibat dalam masalah Illegal Transshipment di laut dalam perspektif UNCLOS 1982 terutama proses penyelesaian sengketa oleh International Tribunal for the Law of The Sea (ITLOS).

\section{A. PENDAHULUAN}

Hukum laut internasional didasarkan pada konsep kebebasan laut, dengan kendali setiap negara ${ }^{1}$ Pada pertengahan abad ke-20, seiring setiap negara dalam meningkatkan kemampuannya untuk terlibat dalam penangkapan ikan jarak jauh dan komersial, muncul kekhawatiran tentang pencemaran dan kerusakan sumber daya laut dan menuntut hak atas sumber daya landas kontinen. ${ }^{2}$ Tentunya, sangat perlu untuk mengembangkan rezim berbasis perjanjian untuk tata kelola laut. Konferensi Perserikatan Bangsa-Bangsa (PBB) tentang hukum laut pada tahun 1958, 1960 dan 1973-1982, menghasilkan sejumlah perjanjian dan mengadopsinya UNCLOS 1982 sebagai konvensi mengenai hukum laut internasional.

Hugo Grotius sebagai ahli dari bidang hukum alam mengungkapkan keberatan terhadap kepemilikan wilayah laut atas dasar dua alasan: Pertama, Tidak ada lautan yang dapat menjadi milik suatu bangsa/negara. Kedua, Alam tidak memberikan hak kepada siapapun untuk memiliki sarana yang dapat dimanfaatkan oleh setiap orang serta yang sifatnya tidak dapat habis (exhaustable) dengan perkataan lain, (res gentium) $)^{3}$ laut terbuka/lepas adalah hak semua bangsa atau (res extra commercium $)^{4}$ barang non-komersial. ${ }^{5}$

UNCLOS 1982 memastikan kerangka hukum untuk mengatur semua penggunaan samudra dan keseluruhan laut internasional yang turut juga mengatur klaim yang tumpang tindih baik di laut teritorial, ZEE dan landas kontinen. ${ }^{6}$ Namun, hal ini tidak selalu terlepas dari berbagai permasalahan. Seperti dengan konsep kebebasan di laut lepas telah menjadi isu bagi berbagai konflik internasional khususnya antara Belanda dan Inggris tentang interpretasi kebebasan di laut. Laut lepas adalah semua bagian laut yang tidak termasuk dalam ZEE, laut territorial, atau perairan pedalaman suatu negara. Implikasi dari definisi tersebut telah menyebabkan laut lepas menjadi wilayah bebas untuk semua negara bagian dan tidak ada negara bagian yang dapat mengklaim wilayah tersebut sebagai bagiannya dari yurisdiksinya ${ }^{7}$ dengan syarat mematuhi ketentuan yang ditetapkan dalam Pasal 87 UNCLOS 1982.

Kebebasan tersebut harus dilaksanakan oleh setiap negara dengan memperhatikan hak

1 Amritha, Shenoy V. (2020), Freedom of the Seas, International Law and the South China Sea Dispute, Centre for International Legal Studies, School of International Studies, Jawaharlal Nehru University, New Delhi, h. 1

2 Tuhulele, Popi. (2011), Upaya Hukum Indonesia Mengajukan Landas Kontinen Ekstensi (antara Peluang dan Tantangan), Perspektif, 16 (3), 184-195. http://dx.DOI.org/10.30742/perspektif.v16i3.82. h. 185.

3 Thomas, Jefferson. (2011), Deen K. Chatterjee (ed.), Encyclopedia of Global Justice, Springer Science Business Media B.V, h. 5, DOI 10.1007/978-1-4020-9160-5

4 Erlc, Wilson. (2002), Mare Liberum And Oplnlo Juris: A Grotian Reading Of The North Sea Continental Shelf Cases. Monash University Law Review, 28 (2), 299-326, http://classic.austlii.edu.au/au/journals/MonashULawRw/2002/13.html. h. 11

5 Yoyon, Darusman M. (2018). Pengaruh UNCLOS Internasional Tahun 1982 Terhadap Wilayah Laut Indonesia (The Influence of the 1982 International Convention on the Law of the Sea against the Indonesian Ocean Territory), Jurnal Cita Hukum (Indonesian Law Journal) 6 (2). DOI: 10.15408/jch.v6i2.8687, h. 2.

6 Sri, Wartini. (2017), The Role Of The Coastal States To The Protection Of Marine Environment In Joint Development Agreement, Indonesian Journal Of International Law, 14 (4). DOI: 10.17304/Ijil.Vol14.4.701, h. 2.

7 Muhammad, Tarigana I., Tjondro, Tirtamuliab. (2020), Strengthening International Law As A Guarantee For High Seas Fisheries Conservation, Bina Hukum Lingkungan, 4 (2), http://dx.DOI.org/10.24970/bhl.v4i2.136. h. 1 .

$$
\text { 13|S A S I Vo1. } 27 \text { No.1, Januari-Maret } 2021
$$


negara lain dalam melakukan hak kebebasan di laut lepas berdasarkan ketentuan dalam UNCLOS 1982. Dari keenam prinsip kebebasan di laut lepas, salah satunya ialah prinsip kebebasan melakukan penangkapan ikan. Kebebasan bukan memberikan kekuasaan bagi pihak manapun, namun kebebasan diberikan dengan konsep perlindungan, hingga kegiatan yang dilakukan di wilayah laut lepas tidak sampai merusak perairan dan sumber daya alam hayatinya. ${ }^{8}$

Prinsip kebebasan di laut internasional tidak terlepas dari berbagai kejahatan maupun pelanggaran hukum internasional. Salah satunya adalah kasus illegal transshipment yang merupakan salah satu kejahatan dalam mencuri ikan. ${ }^{9}$ Illegal transshipment atau pertukaran barang dilakukan antara mode transportasi alternatif, telah menjadi komponen yang penting dari setiap pasokan perikanan yang terjadi baik di pelabuhan atau di laut internasional.

Organisasi Pangan dan Pertanian (FAO) menetapkan transshipment sebagai tindakan mentransfer tangkapan dari satu kapal penangkap ikan ke kapal penangkap ikan lain atau ke kapal yang digunakan semata-mata untuk pengangkutan kargo. ${ }^{10}$ Modusnya, kapal tersebut menjual ikannya di laut lepas tanpa melaporkan hasil tangkapannya, dan pada tangkapan terakhir atau saat periode perizinan hampir berakhir. Saat di kapal pun, pencatatan jumlah ikan yang ditangkap tidak dihitung kembali secara cermat. Jadi melalui transshipment, kapal penangkap tidak perlu lagi kembali ke pangkalan setelah muatan ikan penuh. Kapal penangkap hanya menunggu kapal pengumpul (collecting ship) untuk mengambil ikan hasil tangkapan, dan pada saat itu pula kapal pengumpul menyuplai bahan bakar, bahan makanan, serta kebutuhan lainnya kepada kapal penangkap ikan tersebut. Jelas bahwa transshipment dapat mengefektifkan operasi penangkapan dan mengefisiensikan biaya operasional penangkap. ${ }^{11}$

Kasus illegal transshipment diatas membuktikan bahwa kebebasan untuk memanfaatkan kekayaan alam yang terdapat di laut internasional lama-kelamaan semakin menyimpang, masing-masing negara menghalalkan segala cara untuk meraup kekayaan yang ada di dalam laut dan seringkali dijadikan tempat pelarian bagi kapal-kapal yang melakukan penyelundupan seperti halnya dengan laut lepas juga menjadi tempat langganan terjadinya pembajakan kapal. Semua hal itu terjadi karena adanya anggapan bahwa di laut lepas bebas dilakukan kegiatan apapun oleh setiap negara. Untuk meluruskan anggapan yang selama ini salah, UNCLOS 1982 diadopsi untuk mempersempit luas laut lepas dan memperketat pengawasan di laut lepas sehingga timbul suatu keamanan dan ketertiban di ZEE dengan otomatis kepentingan khusus negara pantai bisa terlindungi dan diharapkan semua negara bisa bekerja sama dalam menjaga kelestarian ekosistem laut sekaligus menjaga keamanan pelayaran di laut sehingga dapat tercipta suatu hubungan internasional yang baik antar negara, khususnya di bidang kemaritiman.

Perkembangannya UNCLOS 1982 secara spesifik telah membagi pengaturan mengenai hak lintas kapal asing di laut internasional seperti hak lintas damai (right of innocent passage), hak lintas transit ${ }^{12}$ (right of transit pessage), dan hak lintas melalui alur-alur kepulauan ${ }^{13}$ (right

8 Puspoayu, Elisabeth Septin., Sari, Cindy Yunita., Ramadhani, Virania Cahya. (2019), Praktik Illegal Transshipment Di Laut Lepas Berdasarkan Hukum Laut Internasional, Jurnal Mimbar Hukum, 31 (1), $76-94$. https://DOI.org/10.22146/jmh.35718, h. 79.

9 Tsamenyi, M., Palma, M., Milligan, B. \& Mfodwo, K. (2010). The European Council regulation on illegal, unreported and unregulated fishing: an international fisheries law perspective. International Journal of Marine and Coastal Law, 25 (1), 5-31. https://doi.org/10.1163/092735210X12589554057604

${ }^{10}$ Satria, Fayakun., Sadiyah, Lilis., Widodo, Agustinus Anung., Wilcox, Chris., Ford, Jessica H., Hardesty, Britta Denise. (2018), Characterizing transshipment at-sea activities by longline and purse seine fisheries in response to recent policy changes in Indonesia. Marine Policy, 95, 8-13, DOI: 10.1016/j.marpol.2018.06.010.

11 Salsabila, Aldhanalia Pramesti. (2018). Pengoptimalan Satgas 115 dengan Model Koordinasi Satgas Pusat dan Daerah Sebagai Bentuk Pencegahan Illegal Transshipment di Indonesia. Lex Scientia Law Review, 2 (1), 5-20. https://journal.unnes.ac.id/sju/index.php/lslr/article/view/23623.

12 United Nations, (2008), United Nations Convention On The Law Of The Sea, New York, Nova Science Publishers Inc, h. 18

13 Dhiana, Puspitawati (2018), Indonesia's Archipelagic Sea Lanes (ASLS) Designation: Rights Turning to Obligations?, Hasanuddin Law Review, 4 (3). DOI: 10.20956/halrev.v4i3.1488, h. 2.

$$
\text { 14|SASI Vol. } 27 \text { No.1, Januari- Maret } 2021
$$


of archipelagic sea lanes pessage) yang masing-masing memiliki sifat dan karakter tersendiri. Berlakunya rezim-rezim pelayaran itu tergantung pada rezim hukum dari wilayah perairan yang berada di bawah kedaulatan negara pantai yang dilalui oleh kapal-kapal asing tersebut. ${ }^{14}$

Pasal 111 UNCLOS 1982 tentang Right of Hot Pursuit menyatakan bahwa pengejaran seketika suatu kapal asing dapat dilakukan apabila pihak yang berwenang dari negara pantai mempunyai alasan cukup untuk mengira bahwa kapal tersebut telah melanggar peraturan perundang-undangan negara tersebiut. Pengejaran seketika (Right of Hot Pursuit) oleh negara pantai dapat memastikan untuk menjaga kredibilitas penegakan yang diperlukan guna menimalisir adanya pelanggaran hukum. ${ }^{15}$

Satu hal penting bahwa UNCLOS 1982 memberikan hak-hak kepada Negara pantai untuk mengatur dan mengawasi lalu lintas damai dalam laut teritoral. Pertama, hak menetapkan keriteria lintas damai. Kedua, wewenang mengeluarkan peraturan perundang-undangan yang terkait dengan lintas damai sebagaimana pasal 21 UNCLOS $1982 .{ }^{16}$

Sekalipun UNCLOS 1982 telah mengatur secara spesifik mengenai tiga hak lintas dan kebebasan di laut internasional. Namun dalam perkembangannya terdapat salah satu kasus yang berkaitan dengan kejahatan atau pelanggaran illegal transshipment diatas, yakni: penangkapan kapal motor Norstars Panama oleh Spanyol di wilayah ZEE Spanyol atas otoritas Italy, Pada tanggal 17 Desember 2015, Panama mengajukan permohonan kepada Pengadilan Hukum Laut Internasional (ITLOS) dalam sengketa dengan Italy mengenai penangkapan dan penahanan $M V$ Norstar, sebuah kapal yang mengibarkan yang bendera Panama. ${ }^{17}$ Selanjutnya adalah kasus Juno trader dimana pada tanggal 23 September 2004, Juno trader menerima angkut kapal di perairan Mauritania dari 1.183,8 ton ikan beku dalam kemasan dan 112 ton makanan ikan, dari kapal saudaranya, Juno Warrior pengalihan tangkapan ikan ini dilakukan ditengah laut tanpa singgah di pelabuhan terdekat. ${ }^{18}$

Secara de facto, permasalahan tersebut telah menjadi perhatian organisasi dunia dan regional sebagai salah satu bentuk kejahatan "Transnational Organized Crime" yang merugikan negara dan mengancam keberlangsungan sumber daya perikanan. United Nations Convention Against Transnational Organized Crime (Palermo Convention) merupakan Konvensi yang mengatur mengenai penetapan standar terhadap hukum nasional masing-masing negara pesertanya, penekanan pada perbedaan sistem hukum negara pesertanya, dan kerjasama yang dapat dibina diantara negara peserta mengenai pemberantasan kejahatan lintas batas terorganisir (Transnational Organized Crime/TOC)

Pasal 73 UNCLOS 1982 menjelaskan bahwa negara pantai dalam melaksanakan hak berdaulat dapat menaiki kapal, memeriksa, menangkap dan melakukan proses pengadilan, sebagaimana diperlukan untuk menjamin ditaatinya peraturan perundang-undangan yang ditetapkan sesuai dengan ketentuan konvensi. Kapal-kapal yang ditangkap dan awaknya harus segera dibebaskan setelah diberikan suatu uang jaminan yang layak. Namun telah terjadi permasalahan hukum yang dinamakan dengan illegal transshipment yang melibatkan kasus penangkapan dan penahanan MV Norstar dan kasus Juno trader yang telah melanggar ketentuan dalam pasal 73 UNCLOS 1982 diatas hingga membawa kasus ini kepada pengadilan

14 Jane, Evangelio Cay Vivien (2010), Archipelagic Sea Lanes Passage And Maritime Security In Archipelagic Southeast Asia, dissertation, Maritime Law and Policy, World Maritime University, Malmö, Sweden, h. 3-4

15 Craig, Allen (2009), Doctrine of hot pursuit: A functional interpretation adaptable to emerging maritime law enforcement technologies and practices, Ocean Development \& International Law, 20 (4), 309-341, DOI: 10.1080/00908328909545899, h. 313.

16 Sodik, M Dikdik, (2016). Hukum Laut Internasional dan Pengaturannya di Indonesia. Bandung: Refika Aditama, h. 30

17 Saputri, R. (t.thn). Sengketa Kapal Motor Norstar. Retrieved from https://www.academia.edu/25452853/Sengketa_Kapal_Motor_Norstar

18 International Tribunal for the Law of the Sea. (2004). The "Juno Trader" Case. Judgement, h. 10

$$
\text { 15|SASI Vo1. } 27 \text { No.1, Januari - Maret } 2021
$$


hukum laut internasional (ITLOS). Berdasarkan uraian latar belakang diatas, penulis mengangkat beberapa permasalahan yang akan dibahas untuk lebih lanjut dengan judul jurnal "Analisis UNCLOS 1982 Terkait Permasalahan Yurisdiksi Negara dan Penegakan Hukum Atas Kapal Berbendera Negara Asing".

Penelitian terdahulu menunjukan telah ada beberapa penelitian lain yang membahas illegal transshipment yaitu Elisabeth Septin Puspoayu, dkk (Jurnal Mimbar Hukum Volume 31, Nomor 1, Februari 2019) tentang "Praktik Illegal Transshipment Di Laut Lepas Berdasarkan Hukum Laut Internasional" dalam penelitian ini di jelaskan bahwa praktik Illegal Transshipment di lakukan oleh kelompok organisasi kriminal dimana adanya modus memindahkan hasil tangkapan ikan dari laut lepas adapun yang menjadi perbedaan penelitian adalah aspek kepastian hukum dan yuridiksi negara pihak ke tiga dalam penegakan Illegal Transshipment.

Penulisan ini terdapat dua rumusan masalah, yaitu: (1) Bagaimana pengaturan UNCLOS 1982 meregulasi pelanggaran Illegal Transshipment di wilayah ZEE negara pantai?: (2) Bagaimana yurisdiksi penegegakkan hukum illegal transshipment yang melibatkan negara ketiga? Adapun dalam penulisan ini menggunakan metode penelitian hukum yuridis normatif dengan penelitian dari data sekunder dan dijelaskan secara deskriptif.

\section{B. METODE PENELITIAN}

Penelitian ini akan mengkaji fokus permasalahan secara normatif. Penelitian hukum normatif merupakan penelitian hukum yang dilakukan dengan cara meneliti bahan pustaka atau data sekunder belaka. ${ }^{19}$ Penelitian hukum normatif dilakukan karena hendak menemukan aturan maupun prinsip-prinsip hukum untuk menyelesaikan fokus permasalahan yang dikaji oleh penulis, dalam penelitian hukum normatif, data sekunder mencakup bahan hukum primer yang meliputi norma atau kaidah dasar, peraturan dasar, peraturan perundang-undangan serta bahan hukum sekunder seperti hasil penelitian, dan hasil karya dari kalangan hukum. ${ }^{20}$ Selanjutnya penulis menggunakan pendekatan perundang-undangan, pendekatan sejarah serta pendekatan konseptual dalam mengkaji artikel ini.

\section{PEMBAHASAN}

\section{Pengaturan UNCLOS 1982 Meregulasi Pelanggaran Illegal Transshipment di Wilayah ZEE Negara Pantai}

Pada umunya, perikanan mempunyai peran penting dan strategis terhadap pembangunan perekonian setiap negara, terutama tentang perluasan kesempatan kerja, pemerataan pendapatan, peningkatan taraf hidup bangsa, pembudidayaan ikan, sampai pada pihak pelaku usaha di bidang perikanan. Hal ini dilakukan dengan tetap mengacu pada lingkungan, kelestarian, dan sumber daya ikan. Dalam hal kegiatan perikanan, cara penangkap ikan dan alat yang dipergunakan berkembang sangat cepat bertujuan untuk memperoleh ikan dalam waktu yang relatif singkat dan cukup besar. ${ }^{21}$

UNCLOS 1982 telah mengatur bahwa setiap negara dengan memperhatikan hak negara lain dalam melakukan segala aktivitas dan hak kebebasan di laut internasional berdasarkan syarat yang telah ditentukan oleh konvensi dan ketentuan lain dalam hukum internasional. Berdasarkan pasal 87 UNCLOS 1982, salah satu dari ke-6 prinsip tersebut salah

19 Soekanto, Soerjono dan Sri Mamudji. (2014). Penelitian Hukum Normatif Suatu Tujuan Singkat, Cetakan ke-16. Jakarta: Raja Grafindo Persada, h. 13-14.

20 Ibid, h.13.

21 Noor, Malia Putri Siti (2018), State Responsibility For Iuu Fishing: A Reflection On The 2015 Itlos Advisory Opinion On Iuu Fishing And Its Relevance To Indonesia, Indonesia Law Review, 8 (2), h. DOI: http://DOI. Org/10.15742/ilrec.v8n2.488, h. 2.

$$
\text { 16|SASI Vo1. } 27 \text { No.1, Januari - Maret } 2021
$$


satunya adalah kebebasan untuk menangkap ikan. Kekebasan bukan berarti memberikan kekuasaan bagi negara manapun, namun kebebesan ini dilakukan untuk konsep perlindungan dan tidak merukan perairan serta sumber daya alam hayati. ${ }^{22}$

Secara regulasi bahwa UNCLOS 1982 hanya mengatur terkait dengan kebebasan setiap negara melintasi laut internasional negara lain berdasarkan pasal 87 UNCLOS 1982. Namun, kebebasan ini sendiri sering kali terjadi pelanggaran maupun kejahatan seperti kasus illegal transshipment dalam kasus Juno trader dan MV.Norstar.

Kasus pertama yakni Juno trader adalah sebuah kapal kargo berpendingin yang disebut "Reefer Vessel" yang mengibarkan bendera Saint Vincent dan Grenadines. Pemiliknya adalah Juno Reefers, sebuah perusahaan yang didirikan di British Virgin Islands dan cabang dari perusahaan makanan laut Afrika Selatan dan berwenang untuk mengangkut produk kering berpendingin. Validitas sertifikat bersifat permanen. Juno trader menerima angkut kapal di perairan Mauritania dari 1.183,8 ton ikan beku kedalam kemasan dan 112 ton makanan ikan, dari kapal saudaranya, Juno trader beroperasi di bawah lisensi Ouguiya di zona ekonomi eksklusif Mauritania. Paket masing-masing ditandai "JW N8607268" sebagai nomor dari Juno Warrior.Juno trader yang kemudian menyeberang ke ZEE Guinea-Bissau pada jarak sekitar 40 mil laut dari pantai. Dan kemudian ditangkap oleh kapal yang berwenang. ${ }^{23}$

Penagkapan kapal Juno trader pada tanggal 23 September 2004, hal ini didasari karena Juno trader menerima angkut kapal di perairan Mauritius (ZEE) dari kapal saudaranya, Juno Warrior. Pada 26 September 2004, Guinea-Bisseau kapal angkatan laut Cacine melakukan operasi kontrol rutin dan pengawasan di ZEE. Inspektur Guinea Bissau telah mengamati kapal tersebut, yang kehadirannya di ZEE tidak diketahui dan tidak dideklarasikan dan akhirnya dilakukan penangapan secara sepihak dengan mengunakan senjata api yang membuat satu awak kapal terluka. Alasan penangkqpan sendiri adalah petugas patroli mengangap kapal tersebut kapal bajak laut sehingga dilakukan tindakan represif. ${ }^{24}$ Dalam kasus ini komite mengusulkan bahwa: $:^{25}$

1) Kapal Juno trader ditemukan telah melanggar ketentuan perundang-undangan Perikanan Guinea-Bissau, mengenai operasi yang berkaitan dengan penangkapan ikan;

2) Sebuah denda dalam Franc CFA sesuai dengan jumlah 175,398 $(175.000,398)$ Euro dikenakan pada kapal Juno trader, atas apa yang dinyatakan dalam paragraf sebelumnya dan sesuai dengan dengan Pasal 56 hukum umum tentang Perikanan;

3) Sebuah denda dalam Franc CFA sesuai dengan jumlah 8,770 (8000, 770) Euro dikenakan, sesuai dengan dengan artikel 58 dari hukum umum Perikanan, pada kapten kapal Juno trader karena kurangnya kerjasama dengan para Inspektur sebagaimana dibuktikan oleh penerbangan kapal;

4) Semua produk di kapal (sekitar $1.183,8$ ton) dinyatakan dikembalikan ke negara Guinea-Bissau atas dugaan telah ditrankresikan di perairan Guinea-Bissau tanpa otorisasi.

Kedua, kasus illegal transshipment yaitu penangkapan kapal motor MV Norstar Panama pada tahun 1994 sampai 1998. MV Norstar itu terlibat dalam memasok gasoil (bahan bakar mesin diesel) untuk yacht mega (kapal pesiar besar) di perairan internasional laut teritorial Spanyol. Permohonan ini lebih lanjut menyatakan bahwa MVNorstar ditangkap di Teluk Palma de Mallorca pada 24 September 1998 oleh pejabat Spanyol, atas permintaan Italy, yang diduga

\footnotetext{
22 Ibid 13

23 International Tribunal for the Law of the Sea (ITLOS). (2004). The "Juno Trader" Case. Judgment, h.

24 The Juno Trader Case (Saint Vincent and the Grenadines v. Guinea-Bissau), International Tribunal for the Law of the Sea Case No 13, 18 Desember 2004, Resumen. Lebih lanjut lihat, informea.org/es/node/223803 (Di akses Tanggal 21 November 2020)

25 The "Juno Trader" Case. Judgment
}

17|SASI Vol. 27 No.1, Januari- Maret 2021 
karena telah dipasoknya minyak untuk yacht mega (kapal pesiar besar) yang bertentangan dengan undang-undang Italy, terkait dengan pelanggaran tersebut dapat dikategorikan sebagai pelanggaran transshipment yakni proses pemindahan muatan dari satu kapal ke kapal lainnya yang terjadi di wilayah ZEE Spanyol yang memicu respon Italy untuk melakukan langkah diplomatis dengan Spanyol menangkap kapal tersebut. ${ }^{26}$ Penangkapan Terhadap kapal motor MV.Norstar ini sendiri telah melanggar ketentuan yang diatur dalam UNCLOS 1982 seperti:

1) Penahanan dari barang-barang yang siap untuk diturunkan dari kapal dengan maksud untuk diturunkan ke darat, penyitaan kapal yang mengangkut barang-barang demikian sudah merupakah suatu yang dinamakan kebiasaan internasional.

2) Penyitaan dari pada barang-barang asal negara asing yang dipindahkan dari suatu kapal ke kapal lainnya di tengah laut untuk diturunkan ke darat atau dimasukkan ke kapal lain yang ada di pelabuhan.

Kapal-kapal dalam melakukan transaksi apapun yang melanggar ketentuan hukum internasional atau yang berkaitan dengan illegal transshipment di wilayah laut suatu negara harus menaati segala ketentuan yang berlaku diwilayah negara tersebut. Akan tetapi, yang terjadi terhadap kapal Juno trader dan kapal MV.Norstar dalam hal ini telah melakukan tindakan illegal transshipment yang telah diatur dalam Pasal 21 UNCLOS 1982.

Pasal 21 UNCLOS 1982 berkaitan dengan Pasal 19 Ayat 2 UNCLOS 1982 yang mendasari bahwa setiap kapal berbendera asing harus dianggap telah merugikan dan membahayakan kedamaian, ketertiban negara pantai jika di laut teritorial terdapat beberapa atau salah satu jenis pelanggaran terkait dengan kegiatan yang diatur dalam pasal 19 dan 21 UNCLOS 1982.

Dari ketentuan Pasal 19 point G dan I dapat dikemukakan bahwa: Pertama, lintasan itu damai selama tidak merugikan kedamaian, ketertiban atau keamanan negara pantai. Kedua, Pasal 19 point $b$ menyebutkan suatu daftar tentang kegiatan-kegiatan yang menyebabkan lintas kapal asing dianggap tidak damai. Dari ketentuan jelas bahwa kapal Juno Trader dan kapal MV.Norstar dianggap telah melanggar Pasal 19 Ayat 2 karena dianggap merugikan negara pantai dengan melakukan illegal transshipment di ZEE negara pantai yang dengan tindakan tersebut berupa pemindahan muatan dari satu kapal ke kapal lainnya yang tentunya merupakan pelanggaran terhadap hukum nasional negara yang bersangkutan dan melanggaran beberapa pasal dari UNCLOS 1982.

Pasal 58 ayat 1 UNCLOS 1982 mengatur terkait dengan yurisdiksi negara pantai pada kedaulatan tertentu seperti hak berdaulat untuk tujuan eksplorasi, dan eksploitasi, konservasi, dan mengelola sumber daya alam hayati di ZEE. Hak kedaulatan ini harus dibedakan dari kedaulatan penuh negara pantai atas teritorial laut, karena merupakan material ratione yang terbatas untuk sumber daya ZEE. Artinya, ZEE menggantikan konsep sebelumnya tentang hak penangkapan ikan preferensial di daerah di luar laut teritorial, terkait dengan pelaksanaan dari hak kedaulatannya. Maka, Negara pantai dapat mengatur perikanan ZEE sesuai dengan pasal 61, 62 UNCLOS $1982^{27}$ dan menegakkan hukum nasionalnya sesuai dengan Pasal 73 UNCLOS $1982 .^{28}$

Penulis juga dalam hal ini memandang ketika sebelum berlakunya UNCLOS 1982, pada hakikatnya pengaturan tentang illegal transshipment telah diatur di beberapa negara sejak pertengahan abad 17 dan 18 antara di negara inggris dan juga amerika serikat sebagimana telah dijelaskan di beberapa negara tersebut illegal transshipment lebih kepada bongkar muat kapal yang melakukan penyulundupan minumaan berakohol akan tetapi dalam prakteknya

26 The M/V "Norstar" Case (Panama v. Italy) ITLOS Case No. 2517 Dec 2015, P. 69-70.

27 Lihar, Article 6162 UNCLOS 1982

28 Valentin, Schatz. (2016), Combating Illegal Fishing in the Exclusive Economic Zone - Flag State Obligations in the Context of the Primary Responsibility of the Coastal State, Goettingen Journal of International Law, 7 (2), DOI: 10.3249/1868-1581-7-2-schatz, h. 5.

$$
\text { 18|S A S Vol. } 27 \text { No.1, Januari - Maret } 2021
$$


pengaturan sepihak antara 2 negara tersebut pada nyatanya menimbulkan konflik oleh karena itu pengaturan secara sepihak illegal transshipment harus dilihat dari kacamata urgensi pengaturan hukum internasional ketika terjadi klaim atas 2 negara yang merasa dirugikan maka UNCLOS 1982 menjadi salah satu induk utama dalam pengaturan tentang illegal transshipment. Pengaturan illegal transshipment bukanlah pelanggaran yang diatur didalam UNCLOS 1982. Namun, jika sebuah kapal melanggar hukum di wilayah laut suatu negara, maka negara tersebut memiliki hak berdaulat untuk menegakkan hukum dan aturan negaranya berdasarkan pasal 73 UNCLOS 1982.

\section{Yurisdiksi Penegakan Illegal Transshipment Yang Melibatkan Negara Ketiga}

Berdasarkan ketentuan Pasal 56 UNCLOS 1982 ditetapkan bahwa dalam zona ekonomi eksklusif (ZEE) negara pantai mempunyai hak berdaulat untuk keperluan eksplorasi, eksploitasi, konservasi, dan pengelolaan sumber daya alam, baik hayati maupun non hayati dari perairan di atas dasar laut dan dari dasar laut serta tanah di bawahnya dan berkenaan dengan kegiatan lain untuk keperluan eksplorasi dan eksploitasi zona ekonomi tersebut, dalam pasal 57 UNCLOS 1982 bahwa setiap negara pantai berhak untuk menetapkan Zona Ekonomi Eksklusifnya yang jaraknya tidak boleh melebihi 200 mil laut di ukur dari garis pangkal laut yang sama yang digunakan untuk mengukur lebar laut teriotialnya.

Aspek positif wilayah negara dalam bentuk adanya kekuasaan tertinggi atau kewenangan ekslusif dari negara di wilayahnya. Sebaliknya di luar wilayahnya suatu ngara tidak lagi memiliki kekuasaan demikian karena kekuasaan itu berakhir dan kekuasaan negara lain mulai. Aspek negatif dari wilayah negara ditunjukan dengan adanya kewajiban negara untuk melindungi hak negara-negara lain di wilayahnya. Dengan demikian, dalam suatu sengketa antara dua negara yang berkaitan dengan kepemilikan terhadap suatu wilayah, yang akan dijadikan bahan pertimbangan oleh mahkamah adalah argumentasi hukum dari salah satu pihak yang dianggap paling kuat.

Kedua kasus penangkapan kapal MV Norstar dan Juno trader seperti yang telah dijelaskan diatas, membuktikan bahwa terdapat tindakan represif yang jelas melanggar ketetuan Pasal 27 ayat (1) UNCLOS 1982 menjelaskan bahwa: Yurisdiksi kriminal Negara pantai tidak dapat dilaksanakan di atas kapal asing yang sedang melintasi laut teritorial untuk menangkap siapapun atau untuk mengadakan penyidikan yang bertalian dengan kejahatan apapun yang dilakukan di atas kapal selama lintas demikian, kecuali dalam hal yang berikut : (a) apabila akibat kejahatan itu dirasakan di Negara pantai; (b) apabila kejahatan itu termasuk jenis yang mengganggu kedamaian Negara tersebut atau ketertiban laut wilayah; (c) apabila telah diminta bantuan penguasa setempat oleh nakhoda kapal oleh wakil diplomatik atau pejabat konsuler Negara bendera; atau (d) apabila tindakan demikian diperlukan untuk menumpas perdagangan gelap narkotika atau bahan psychotropis.

Dari penjalasan pasal 27 diatas Spanyol memiliki yuridiksi terhadap kapal MV Norstar diwilayah ZEE Spanyol. Akan tetapi, ketika pelanggaran yang dilakukan oleh kapal asing yang berkaitan dengan pasal 27 diatas, intruksi dari Italy tidak bisa dijadikan dasar Spanyol dalam penangkapan $M V$ Norstar tersebut dan pada pelaksaannya $M V$ Norstar tidak melanggar ketententuan Pasal 27 yang berdampak besar terhadap negara yang bersangkutan. Italy melakukan permintaan kepada Spanyol untuk melakukan penangkapan terhadap MV Norstar yang dapat dikatakan telah melanggar beberapa Pasal 33 UNCLOS 1982 terkat dengan Zona Tambahan.

Pasal 33 UNCLOS 1982 dapat diketahui bahwa Italy seharusnya tidak memiliki kedaulatan untuk melakukan penangkapan atau bahkan penahanaan terhadap MV Norstar dan

$$
\text { 19|SASI Vo1. } 27 \text { No.1, Januari - Maret } 2021
$$


didukung dengan Pasal 33 Ayat 1 (b) UNCLOS 1982. Italy tidak memiliki otoritas atau yuridiksi untuk menghukum pelanggaran $M V$ Norstar dikarenakan kapal ini berada dalam wilayah zona ekonomi ekslusif Spanyol. Pasal 73 UNCLOS 1982 tentang Penegakan Peraturan Perundangundangan Negara Pantai dijelaskan bahwa "Hukuman Negara pantai yang dijatuhkan terhadap pelanggaran peraturan perundang-undangan perikanan di zona ekonomi eksklusif tidak boleh mencakup pengurungan, jika tidak ada perjanjian sebaliknya antara Negara-negara yang bersangkutan, atau setiap bentuk hukuman badan lainnya." Pada ayat ini dengan sangat jelas dituliskan bahwa tidak bisa terdapat hukuman kurungan bagi kapal MV.Norstar tersebut di wilayah ZEE suatu negara, kecuali jika telah adanya perjanjian antara kedua negara antara Panama dan Italy.

Sedangkan dalam kasus Juno Trader dan berkaitan dengan pertimbangan diatas. Maka, tindakan yang dilakukan oleh Guinea-Bissau sendiri tidak mempunyai landasan yang kuat karena kapal tersebut hanya sebagai kapal penangkapan ikan biasa yang dianggap sebagai kapal bajak laut yang melintas di ZEE Guinea-Bissau. Jika melihat pasal 27 diatas jelas penangakapan serta tindakan yang dilakukan 2 negara melangar Pasal 27. Hal in juga berlaku terhadap kapal Juno trader yang ditahan di bawah pengawasan personil bersenjata di negara Guinea-Bissau.

Italy dan Guinea-Bissau pada dasarnya tidak memiliki kewenangan untuk melakukan pengejaran dan penangkapan terhadap kapal MV Norstars dan Juno Trader yang kemudian telah mengambil tindakan penahanan yang mana sangat bertentangan dengan Pasal 27 ayat (3) yang menjelaskan pula dalam hal penangkapan atau penahanan kapal asing Negara pantai harus segera memberitahukan kepada Negara bendera, melalui saluran yang tepat, mengenai tindakan yang diambil dan mengenai setiap hukuman yang kemudian dijatuhkan. Italy juga telah melanggar Pasal 87 UNCLOS 1982 menjelaskan bahwa, bahwa "Laut lepas terbuka untuk semua Negara, baik Negara pantai atau tidak berpantai. Kebebasan laut lepas, dilaksanakan berdasarkan syarat-syarat yang ditentukan dalam Konvensi ini dan ketentuan lain hukum internasional. Kapal $M V$ Norstar yang melakukan pemasokan gasoli seharusnya tidak melanggar ketentuan apapun berdasarkan penjabaran Pasal 87 UNCLOS 1982. Jika Italy berpendapat bahwa pemasokan gasolin terhadap yacht mega ini bertentangan dengan aturan hukum negara Italy, maka transaksi pemasokan gasoli ini tidak ada kaitannya secara langsung dengan negara Italy, dalam praktiknya meninstruksikan Spanyol untuk menangkap kapal tersebut jelaslah hal tersebut sangat tidak memiliki kejelasan, dasar dan yuridiksi atas intrustruksi tersebut.

Terkait dengan pengejaran dari dua kapal diatas. Maka, mengacu terhadap Pasal 111 UNCLOS 1982 tentang Right of Hot Pursuit yang menjelaskan bahwa pengejaran seketika adalah hak tiap negara pantai untuk melaksanakan tindakan pengejaran seketika terhadap kapal asing yang diduga melanggar peraturan perundang-undangan negara pantai dimulai dari Perairan Pedalaman, Perairan Kepulauan, Laut Territorial atau Jalur Tambahan, dan juga berlaku terhadap pelanggaran-pelanggaran di wilayah Zona Ekonomi Eksklusif (ZEE) dan Landas Kontinen dari negara pantai sampai ke laut teritorial negara kapal asing atau negara ketiga. $^{29}$

Artinya, pengejaran dan penangkapan seharusnya dilakukan apabila pihak yang berwenang dari negara pantai mempunyai alasan cukup untuk mengira bahwa kapal tersebut telah melanggar peraturan perundang-undangan negara Spanyol, namun dalam kasus ini, Italy sama sekali tidak memilliki kewenangan terhadap $M V$ Norstar dan malah meminta Pejabat

29 Paulantzaaz, N. M. (2002). The Right of Hot Pursuit in International Law, Second Edition. The Hague: Martinus Nijhoff Publishers, h. 39.

$$
\text { 20|SASI Vol. } 27 \text { No.1, Januari-Maret } 2021
$$


Spanyol yang berwenang melakukan pegejaran, penangkapan, serta penahanan terhadap $M V$ Norstar. Pelaksanaan Right of Hot Pursuit haruslah dimulai dari perairan pedalaman, laut wilayah atau zona tambahan negara pantai setelah perintah berhenti tidak dihiraukan; harus terus menerus dan tidak terputus; Hot Pursuit dihentikan setelah kapal asing dikejar memasuki laut wilayah negaranya tau negara ketiga; dan pengejaran yang dimulai dari zona tambahan hanya berlaku terhadap pelanggaran mengenai masalah bea cukai, keuangan, imigrasi dan karantina. Sedangkan, dalam kasus Juno trader Pengejaran seketika dilakukan dengan adanya indikasi yang dilakukan oleh kapal Juno trader yang dalam perkembanganya terbukti di persidangan atas dasar bukti sampel ikan yang hidup di perairan ZEE Guinea-Bissau yang dianggap melanggar peraturan perundang-undangan di negara tersebut.

Dari kedua kasus diatas, pada dasarnya Spanyol mempunyai yurisdiksi terhadap $M V$ Norstar. Tetapi tidak untuk sampai ke tahapan penangkapan dan penahanan karena kapal tersebut tidak melanggaran perundang-undangan Spanyol dan Italy juga secara jelas tidak memiliki yuridiksi atas penangkapan $M V$ Norstar yang menggunakan hubungan diplomatis dengan Spanyol untuk menangkap kapal $M V$ Norstar, pengejaran serta penangkapan tidak sesuai dengan mekanisme yang diatur dalam UNCLOS 1982, mengingat MV Norstar adalah kendaraan air legal dengan sertifikat, catatan, dan dokumen yang lengkap dan resmi dari negara Panama. Sedangkan dalam kasus Juno Trader, ITLOS dihadapkan dengan masalah transshipment dan transportasi yang melakukan penakapan ikan, tetapi secara tegas membahas mengenai kompetensi dari negara pantai. Maka, dapat dikatakan terlalu dini untuk melakukan penangkapan terhadap kapal tersebut, karena diduga telah melakukan transshipment. Namun, hal ini sama sekali tidak terbukti dan serta mengangap kapal tersebut kapal bajak laut sehingga dilakukan tindakan represif seperti penangkapan dan penahanan yang tentunya telah melanggar beberapa ketentuan dari UNCLOS 1982.

\section{P E N U T U P}

Berdasarkan hasil pembahasan dalam penelitian ini, adanya pengaturan yang lebih komperhensif tentang illegal transshipment dalam UNCLOS 1982. Mengenai kasus pertama UNCLOS 1982 belum mengatur permintaan negara lain terhadap penindakan kapal yang di indikasi melakukan illegal transshipment dalam hal ini kapal MV.Norstar yang di indikasi melakukan pelanggaran di ZEE Italy tetapi ditangkap diperairan Spanyol atas dasar permintaan Italy, padahal kapal ini tidak melanggar Ketentuan perundang-undangan Spanyol. Disamping itu, Penangkapan illegal transshipment atas dasar indikasi tidak dapat dilakukan karena membuat penangkapan kapal tidak mempunyai dasar dan bukti dan kuat. Walaupun dalam kasus Juno Trader terbukti melakukan penangkapan ikan ilegal dengan sampel yang diambil oleh negara Guinea tetapi hal ini menjadi permasalahan ketika penangkapan yang dilakukan tidak terbukti melakukan pelanggaran Hukum. Permasalahan ini menjadi krusial karena harus memperhatikan kerugian material maupun imaterial dari kapal yang ditangkap. Intinya harus ada mekanisme yang eksplisit mengenai tanggungjawab negara ketika terjadi kesalahan penangkapan atau indikasi yang tidak terbukti. Tanggungjawab harus dibayar atau diganti oleh negara yang menangkap baik secara material dan imaterial.

\section{DAFTAR PUSTAKA}

\section{Jurnal}

[1] Craig, Allen (2009), Doctrine of hot pursuit: A functional interpretation adaptable to emerging maritime law enforcement technologies and practices, Ocean Development \& International Law, 20 (4), 309-341, DOI: 10.1080/00908328909545899.

[2] Dhiana, Puspitawati (2018), Indonesia's Archipelagic Sea Lanes (ASLS) Designation:

$$
\text { 21|SASI Vo1. } 27 \text { No.1, Januari - Maret } 2021
$$


Rights Turning to Obligations?, Hasanuddin Law Review, 4 (3). DOI: $10.20956 /$ halrev.v4i3.1488.

[3] Erlc, Wilson. (2002), Mare Liberum And Oplnlo Juris: A Grotian Reading Of The North Sea Continental Shelf Cases. Monash University Law Review, 28 (2), 299-326, http://classic.austlii.edu.au/au/journals/MonashULawRw/2002/13.html.

[4] Muhammad, Tarigana I., Tjondro, Tirtamuliab. (2020), Strengthening International Law As A Guarantee For High Seas Fisheries Conservation, Bina Hukum Lingkungan, 4 (2), http://dx.DOI.org/10.24970/bhl.v4i2.136.

[5] Noor, Malia Putri Siti (2018), State Responsibility For Iuu Fishing: A Reflection On The 2015 Itlos Advisory Opinion On Iuu Fishing And Its Relevance To Indonesia, Indonesia Law Review, 8 (2), h. DOI: http://DOI. Org/10.15742/ilrec.v8n2.488.

[6] Puspoayu, Elisabeth Septin., Sari, Cindy Yunita., Ramadhani, Virania Cahya. (2019), Praktik Illegal Transshipment Di Laut Lepas Berdasarkan Hukum Laut Internasional, Jurnal Mimbar Hukum, 31 (1), 76-94. https://DOI.org/10.22146/jmh.35718.

[7] Sri, Wartini. (2017), The Role Of The Coastal States To The Protection Of Marine Environment In Joint Development Agreement, Indonesian Journal Of International Law, 14 (4). DOI: 10.17304/Ijil.Vol14.4.701.

[8] Satria, Fayakun., Sadiyah, Lilis., Widodo, Agustinus Anung., Wilcox, Chris., Ford, Jessica H., Hardesty, Britta Denise. (2018), Characterizing transshipment at-sea activities by longline and purse seine fisheries in response to recent policy changes in Indonesia. Marine Policy, 95, 8-13, DOI: 10.1016/j.marpol.2018.06.010.

[9] Salsabila, Aldhanalia Pramesti. (2018). Pengoptimalan Satgas 115 dengan Model Koordinasi Satgas Pusat dan Daerah Sebagai Bentuk Pencegahan Illegal Transshipment di Indonesia. Lex Scientia Law Review, 2 (1), 5-20. https://journal.unnes.ac.id/sju/index.php/lslr/article/view/23623.

[10] Tsamenyi, M., Palma, M., Milligan, B. \& Mfodwo, K. (2010). The European Council regulation on illegal, unreported and unregulated fishing: an international fisheries law perspective. International Journal of Marine and Coastal Law, 25 (1), 5-31. https://doi.org/10.1163/092735210X12589554057604

[11] Tuhulele, Popi. (2011), Upaya Hukum Indonesia Mengajukan Landas Kontinen Ekstensi (antara Peluang dan Tantangan), Perspektif, 16 (3), 184-195. http://dx.DOI.org/10.30742/perspektif.v16i3.82.

[12] Valentin, Schatz. (2016), Combating Illegal Fishing in the Exclusive Economic Zone Flag State Obligations in the Context of the Primary Responsibility of the Coastal State, Goettingen Journal of International Law, 7 (2), DOI: 10.3249/1868-1581-7-2-schatz.

[13] Yoyon, Darusman M. (2018). Pengaruh UNCLOS Internasional Tahun 1982 Terhadap Wilayah Laut Indonesia (The Influence of the 1982 International Convention on the Law of the Sea against the Indonesian Ocean Territory), Jurnal Cita Hukum (Indonesian Law Journal) 6 (2). DOI: 10.15408/jch.v6i2.8687.

\section{Buku}

[14] Amritha, Shenoy V. (2020), Freedom of the Seas, International Law and the South China Sea Dispute, Centre for International Legal Studies, School of International Studies, Jawaharlal Nehru University, New Delhi.

[15] Paulantzaaz, N. M. (2002). The Right of Hot Pursuit in International Law, Second Edition. The Hague: Martinus Nijhoff Publishers.

[16] Soekanto, Soerjono dan Sri Mamudji. (2014). Penelitian Hukum Normatif Suatu Tujuan Singkat, Cetakan ke-16. Jakarta: Raja Grafindo Persada.

[17] Sodik, M Dikdik, (2016). Hukum Laut Internasional dan Pengaturannya di Indonesia. Bandung: Refika Aditama.

[18] Thomas, Jefferson. (2011), Deen K. Chatterjee (ed.), Encyclopedia of Global Justice, Springer Science Business Media B.V, h. 5, DOI 10.1007/978-1-4020-9160-5. 


\section{Disertasi dan Lain-Lain}

[19] International Tribunal for the Law of the Sea (ITLOS). (2004). The "Juno Trader" Case. Judgment

[20] Jane, Evangelio Cay Vivien (2010), Archipelagic Sea Lanes Passage And Maritime Security In Archipelagic Southeast Asia, dissertation, Maritime Law and Policy, World Maritime University, Malmö, Sweden.

[21]Saputri, R. (t.thn). Sengketa Kapal Motor Norstar. Retrieved from https://www.academia.edu/25452853/Sengketa_Kapal_Motor_Norstar.

[22] The Juno Trader Case (Saint Vincent and the Grenadines v. Guinea-Bissau), International Tribunal for the Law of the Sea Case No 13, 18 Desember 2004, Resumen. Lebih lanjut lihat, informea.org/es/node/223803. 